IZA DP No. 4729

Greasing the Wheels of International Commerce: How Services Facilitate Firms' International Sourcing

Peter Debaere Holger Görg Horst Raff

January 2010 


\title{
Greasing the Wheels of International Commerce: How Services Facilitate Firms' International Sourcing
}

\author{
Peter Debaere \\ University of Virginia and CEPR \\ Holger Görg \\ University of Kiel, Kiel Institute for the World Economy, \\ CEPR and IZA \\ Horst Raff \\ University of Kiel \\ and Kiel Institute for the World Economy
}

Discussion Paper No. 4729

January 2010

IZA

P.O. Box 7240

53072 Bonn

Germany

Phone: $+49-228-3894-0$

Fax: +49-228-3894-180

E-mail: iza@iza.org

Any opinions expressed here are those of the author(s) and not those of IZA. Research published in this series may include views on policy, but the institute itself takes no institutional policy positions.

The Institute for the Study of Labor (IZA) in Bonn is a local and virtual international research center and a place of communication between science, politics and business. IZA is an independent nonprofit organization supported by Deutsche Post Foundation. The center is associated with the University of Bonn and offers a stimulating research environment through its international network, workshops and conferences, data service, project support, research visits and doctoral program. IZA engages in (i) original and internationally competitive research in all fields of labor economics, (ii) development of policy concepts, and (iii) dissemination of research results and concepts to the interested public.

IZA Discussion Papers often represent preliminary work and are circulated to encourage discussion. Citation of such a paper should account for its provisional character. A revised version may be available directly from the author. 


\section{ABSTRACT \\ Greasing the Wheels of International Commerce: How Services Facilitate Firms' International Sourcing*}

We use unique plant-level data to study the link between the local availability of services and the decision of manufacturing firms to source materials from abroad. To guide our empirical analysis we develop a monopolistic-competition model of the materials sourcing decisions of heterogeneous firms. The model generates predictions about how the intensity of international sourcing of materials depends on a firm's productivity and the availability of local services. These predictions are supported by the data. We find evidence that more productive manufacturing firms tend to have a higher ratio of imported materials to sales. In addition, we find evidence that services grease the wheels of international commerce: A greater availability of services across regions, industries and time increases a firm's foreign sourcing of materials relative to sales. Interestingly, this positive impact of local service availability on imports especially applies to stand-alone firms that, unlike multinationals, are less likely to rely on imported or internally provided services.

JEL Classification: F12, L23

Keywords: international trade, services, off-shoring, supply chain management, firm heterogeneity

Corresponding author:

Holger Görg

University of Kiel

Institut für Volkswirtschaftslehre

Wilhelm-Seelig-Platz 1

24118 Kiel

Germany

E-mail: goerg@economics.uni-kiel.de

\footnotetext{
* The paper was started while Peter Debaere visited the Kiel Institute for the World Economy. The authors benefited from suggestions by Giorgio Barba Navaretti, Ed Davis, Mary Lovely, James Harrigan, John McLaren, Gal Raz and audiences at the CEPR services workshop in Milan, Deardorff's Festschrift Conference at the University of Michigan, and seminars at the Kiel Institute for the World Economy and at the Universities of Aachen, Aarhus, Tübingen and Virginia. Holger Görg is also affiliated with GlobID at Aarhus School of Business and acknowledges financial support from the Tuborg Foundation. Horst Raff acknowledges financial support from the German Science Foundation.
} 


\section{Introduction}

International sourcing plays a very important role in the production process within the global economy. As a matter of fact, the growth in intermediate goods trade is often referred to as a factor that distinguishes the current wave of globalization from previous ones. ${ }^{1}$ Just consider the many sources of inputs for an iPod, sold by the U.S. company Apple. Dedrick et al.(2009) show that the hard-drive is produced by the Japanese company Toshiba using affiliates based in China. The display module and display driver are produced in Japan, while some smaller inputs are also supplied from Korea. The final assembly is carried out by a Taiwanese company in a plant in China. Furthermore, US suppliers provide the video/multimedia processor as well as the portal player CPU.

Firms' international sourcing (also referred to as offshoring) decisions and their implications have been the subject of much recent theoretical and empirical analysis, as summarized by Helpman (2006). What has received less attention in the economics literature, however, is the role that services play in organizing and optimizing these sourcing processes. It has been argued that services such as transportation, insurance, financing, etc. grease the wheels of international commerce in the sense that they play an important role in facilitating trade. Francois (1990), Deardorff (2001), Jones and Kierzkowski (1990), as well as Golub et al. (2001) have emphasized how the increased availability of more differentiated or more affordable services can, in addition, make it easier for firms to exploit the international division of labor, and to split production into parts that can be made in different locations. It is in the process of fragmentation of production that computer and business services should be of particular importance.

In this paper we focus specifically on the role of computer and business services in the organization of international trade. We study the link between the availability of those services and trade in intermediate manufacturing goods. The main contribution of the current paper is thereby to provide empirical evidence (motivated by a simple heterogeneous firm type model) on how this process of greasing the wheels of international commerce works at the micro level. For this purpose, we focus on imports of materials and investigate whether the availability of local services induces manufacturing

\footnotetext{
${ }^{1}$ See, for instance, Hummels et al. (2001). Yi (2003) has hypothesized that the increased fragmentation of production and the resulting trade in intermediates is an important factor behind the growth of international trade.
} 
firms to source more material inputs from abroad. Our study relies on firmlevel data, and we use two features of this data to isolate the effect of services: (i) information on the variation in service availability across regions, time and industry, and (ii) information on firm size, labor productivity and firm status as national or multinational firm that, as we will show, are likely to be correlated with a firm's dependence on local services. ${ }^{2}$

While the link between services and international sourcing has not received much attention in the economics literature so far, the business literature, for some time now, has emphasized the importance of services for organizing a firm's production. ${ }^{3}$ Supply-chain management, in particular, sees the challenge exactly in coordinating and integrating an increasingly sliced-up-value chain. ${ }^{4}$ Off-shoring and outsourcing have matured, it is often argued, and the main question is no longer whether or not a well-defined part of production should be produced by an affiliate or stand-alone firm abroad or at home. Rather, the current focus is on managing and integrating the whole process of production across its different stages from the purchase of raw materials to the distribution to the customer. It is in this process that service firms, and in particular those providing business and computing services, have a vital role to play.

Consider, for example, a car producer with an extended supply chain of hundreds of suppliers. These suppliers send their parts at different times, through different channels and in different packages to the car manufacturer. Not only is it important that the parts eventually reach the car producer, there is ample room to optimize this process. The time and arrival of parts have to be coordinated, damage and losses have to be minimized, international customs paperwork has to be taken care of for the pieces coming from abroad, and parts have to be warehoused before being shipped to the manu-

\footnotetext{
${ }^{2}$ Our focus is primarily on the demand for producer services and how it relates to the production side of the economy, rather than on the demand for consumer services that was the main focus of the earlier literature on the Balassa-Samuelson effect and the 'Baumol disease'. See Francois and Hoekman (2009) for a discussion.

${ }^{3}$ There is a booming literature that studies firm heterogeneity and that explores a wide range of firm activities relating to firms' export and import decisions as well as their multinational strategies. See Helpman (2006) who surveys work by Antras, Helpman, Melitz, and others. While this literature has been primarily applied to manufacturing, there is a growing interest in studying to what extent the models also apply to services, see Oldenski (2009) and Breinlich and Criscuolo (2009). So far, however, the specific links between services and goods trade have received little attention.

${ }^{4}$ See Gachon and Terwiesch (2009) and Corbett (2004).
} 
facturer. There are ample opportunities for third-party service providers to get involved in this process. ${ }^{5}$ Moreover, many service firms have extended their operations into the IT sphere and become increasingly more involved in the manufacturer's operations: They can set up a tracking system where companies can see in real time where their supplies are, and make suggestions for the optimal bunching of suppliers.

Our analysis has a theoretical and an empirical component. The theoretical component consists of a simple model of the sourcing decisions of heterogeneous firms in the manufacturing sector. This model is used to derive predictions about how these decisions are affected by firm characteristics and the availability of services. In particular, we show how the increased availability of services should raise the ratio of imported intermediates to sales especially for firms that have to rely on local services because they are too small or inefficient to provide the services themselves or to import them. The model is related to Raff and Schmitt (2009) who study sourcing decisions of retail firms, and to Bas (2008) who studies the effect of trade barriers in input and final goods markets on production and exporting decisions. Both of these papers build on Melitz and Ottaviano (2008). Our model differs from Antras and Helpman's (2004) analysis of international sourcing in at least two important respects. First, we do not consider the question of whether firms off-shore or not but rather how much they offshore. Second, we do not deal with the question of whether the production of materials is done in-house or by independent suppliers. Instead we focus on the question of how firms procure the services needed for importing materials.

To investigate the empirical relevance of our predictions about the sourcing behavior of firms, we use an unbalanced panel of Irish plants from the Annual Business Survey of Economic Impact that runs from 2000 to 2004. The dataset is quite unique in that it documents the sourcing behavior in great detail, explicitly distinguishing between materials and services as well as between domestic and international inputs. Note that for Irish firms domestic and international sourcing are just a fact of life: In our sample, around $90 \%$ of manufacturers source some foreign-produced materials and virtually all manufacturing firms (94\%) source materials in the Irish economy, which

\footnotetext{
${ }^{5}$ The business literature sometimes refers to third-party service providers as third-party logistics firms. There are ample cases studies of such third-party logistics firms, including UPS (http://www.ups-scs.com/solutions) in the United States, or Accenture in Ireland ("Guide to strategic outsourcing in Ireland", http://www.accenture.com/xdoc/ir/locations/ireland/insights/guide.pdf).
} 
is why we focus on how much is off-shored, rather than whether there is any off-shoring occurring at all.

As far as services go, the Survey focuses on business and computing services, which are directly relevant for our study. In the empirical analysis, we exploit a particular feature of the data to get at the impact of services on the extent of material imports of firms. The Annual Survey indicates whether a plant is located in one of three of Ireland's relatively different regions: the capital Dublin, the South, and the rest of the country. In our analysis we investigate how variations in the availability of services across regions, time and/or industry affect the international sourcing intensity of Irish plants, specifically the ratio of off-shored inputs to sales. Needless to say, we rationalize this focus on the local availability of service with the distinguishing characteristics of services: As Oldenski (2009) documents, services are much more dependent on face-to-face contact ("working with the public") than, say, manufacturing.

Ireland is singularly fit for studying the questions that we are investigating. ${ }^{6}$ First, Ireland is a small, open economy with a trade to GDP ratio of over 80 percent that is widely regarded as very well positioned entry point into the European market. Ireland has attracted multiple well-known multinational corporations in electronics, pharmaceuticals and medical appliances and more recently in services, some of which have chosen it as a base for off-shoring. ${ }^{7}$ Moreover, in terms of services and service trade Ireland has clearly excelled. In spite of its size, Ireland was, according to the OECD (2009), in absolute terms about the world's ninth largest exporter of services in 2007. Second, Ireland wants to promote itself increasingly as an area that is especially well-suited for supply chain management. As a matter of fact, the Irish Development Agency (IDA) that tries to promote Ireland's image abroad explicitly links Ireland with supply chain management in its publi-

\footnotetext{
${ }^{6}$ Haider, Don (2005), Ireland: Celtic Tiger, Kellogg School of Management KEL 141. Alfaro, Laura, Dev, Vinati and Stephen McIntyre (2008), Foreign Direct Investment and Ireland's Tiger Economy, Harvard Business School, 9-706007. See also, Enterprise Ireland's Ireland Economic Profile, http://www.enterpriseireland.com/SourceIreland/Ireland/Economy.htm

${ }^{7}$ Two very good references on the service discussion in Ireland are: Catching the Wave. A service Strategy for Ireland, Report of the Service Strategy Group, 2008; and also the background report: http://www.forfas.ie/publications/forfas080912/forfas080912_services_strategy.pdf http://www.forfas.ie/publications/forfas080912/forfas080912_services_ strategy_background.pdf
} 
cations. $^{8}$ Moreover, the Irish success story has been built to a large extent on sectors that should be especially conducive to supporting off-shoring in goods: Ireland has an impressive IT sector, and has increasingly been able to attract financial, insurance, R\&D and headquarter services.

Our empirical results are quite encouraging. We find that both a greater local availability of services and a higher labor productivity significantly increase a firm's foreign sourcing of materials as a fraction of sales. Interestingly, when we distinguish between local Irish firms, Irish multinationals and Irish affiliates of foreign multinationals, we find that the local availability of service firms only seems to matter for the local Irish firms, not for the multinationals. This result is quite intuitive as it suggests that multinationals may be importing or may have internalized to a larger extent the services upon which they rely for their international transactions.

The rest of the paper is structured as follows. In the next section, we lay out the model. Comparative static effects are derived in Section 3. In Section 4, we present the empirical model, and in Section 5 we describe the dataset. The results of our estimation are reported in Section 6, Section 7 concludes, and the Appendix contains proofs.

\section{The Model}

In this section, we develop a simple model of material-input sourcing by firms in the manufacturing sector. There is a continuum of manufacturing firms selling their finished products in the domestic (Irish or European) market. From the consumers' point of view, these products are differentiated varieties. We index firms by $i \in \Omega$, and assume that all consumers share the same quasi-linear utility function:

$$
U=\alpha \int_{i \in \Omega} q_{i}^{c} d i-\frac{1}{2} \beta \int_{i \in \Omega}\left(q_{i}^{c}\right)^{2} d i-\frac{1}{2} \gamma\left(\int_{i \in \Omega} q_{i}^{c} d i\right)^{2}+y,
$$

where $q_{i}^{c}$ denotes the quantity per capita bought from firm $i$, and $y$ the consumption of the numeraire good. Parameter $\beta$ describes the degree of substitutability between the different varieties of manufactures. The degree of product differentiation increases with $\beta$. If $\beta=0$, goods are perfectly substitutable, and consumers care only about their total consumption level, $Q^{c}=\int_{i \in \Omega} q_{i}^{c} d i$

\footnotetext{
${ }^{8}$ For a discussion of supply chain management in Ireland, see Sweeney et al. (2008).
} 
Assuming that the demand for the numeraire is positive, the inverse percapita demand faced by each firm $i$ is

$$
p_{i}=\alpha-\beta q_{i}^{c}-\gamma Q^{c}
$$

Denoting by $L$ the number of consumers and by $N$ the mass of active firms, the market demand faced by firm $i$ can be expressed as a function of the firm's own price, $p_{i}$, and the average price in the market, $\bar{p}$ :

$$
q_{i}\left(p_{i}\right) \equiv L q_{i}^{c}=\frac{\alpha L}{\gamma N+\beta}-\frac{L}{\beta} p_{i}+\frac{\gamma N}{\gamma N+\beta} \frac{L}{\beta} \bar{p}
$$

where

$$
\bar{p}=\frac{1}{N} \int_{i \in \Omega^{*}} p_{i} d i
$$

and where $\Omega^{*}$ is the set of active firms. Firms are monopolistically competitive. That is, they take $N$ and $\bar{p}$ as given when deciding on prices. In what follows, we will drop firm subscripts whenever possible.

Labor, the only factor of production, is inelastically supplied and perfectly mobile across sectors. Since the numeraire good is produced by a competitive industry under constant returns and a unit labor requirement of one, the price of labor in the economy is equal to one. All costs can therefore be expressed in terms of labor requirements.

Finished goods are produced using labor $(l)$ and a composite material input $(x)$ according to the Leontief technology $q=\min \{l / c, x\}$, where $1 / c$ represents labor productivity. ${ }^{9}$ The composite material input $(x)$ combines domestic materials $(z)$ and imported materials $(m)$ according to the following CES production function:

$$
x=\left(z^{\phi}+m^{\phi}\right)^{\frac{1}{\phi}}
$$

with $0<\phi<1$. Domestic and imported materials are hence imperfect substitutes with an elasticity of substitution equal to $\theta=1 /(1-\phi)$. For simplicity we assume that both $z$ and $m$ are produced using one unit of labor per unit of output, which is tantamount to having prices of $z$ and $m$ equal to one.

\footnotetext{
${ }^{9}$ The assumption that labor and materials are complements is made for analytical convenience. Our results would go through even if labor and materials were substitutes, provided that the elasticity of substitution is not too big.
} 
Firms first decide whether to enter the market and thus whether to incur the sunk cost $F_{E}$. Upon entering, each firm learns its labor productivity $1 / c$. We assume that $1 / c$ follows a Pareto distribution, which implies the following cumulative distribution $G(c)$ for the marginal labor cost with support on $\left[0, c_{M}\right]$ :

$$
G(c)=\left(\frac{c}{c_{M}}\right)^{k}
$$

where $k \geq 1$.

Then follows the decision on what price to charge and how to procure materials. Sourcing materials from abroad requires services, such as transportation, trade financing, business services like insurance and accounting, and the more process-oriented supply-chain services. There are two ways of obtaining these services. First, a firm may buy them from local service providers; we refer to this as mode $D$. We assume that the margin paid to local service firms is $\delta-1$ per unit of imported materials with $\delta>1$. Since imported materials trade at a price of unity, the gross price of imported materials in mode $D$ (including the service margin) is $\delta .{ }^{10}$ Second, the firm may obtain the services necessary for importing materials without going through the local service market. That is, it may internalize the provision of services, or import services from abroad. This is mode $I$. Mode $I$ involves a fixed cost, $F_{I}$, associated with operating an own service department, or with identifying and communicating with foreign service providers. But by incurring this fixed cost, the margin on service purchases is reduced below $\delta-1$; for simplicity, we normalize this margin to zero so that imported materials in mode $I$ carry a gross unit price of one. Mode $D$ is hence associated with a higher variable cost than mode $I$. A trade-off occurs in the choice of mode because mode $I$ involves a fixed cost.

Cost minimization by a manufacturer implies the following conditional demands for imported materials depending on the sourcing mode:

$$
\begin{aligned}
& m^{D}(q)=\delta^{\frac{1}{\phi-1}}\left(1+\delta^{\frac{\phi}{\phi-1}}\right)^{-\frac{1}{\phi}} q, \\
& m^{I}(q)=(2)^{-\frac{1}{\phi}} q .
\end{aligned}
$$

\footnotetext{
${ }^{10}$ In the empirical section, we use a measure of local services availability to proxy for the service margin $\delta-1$. The idea is that a greater availability of local services leads to lower service prices and greater service variety, which implicitly reduces the cost of using local service providers.
} 
The total cost of materials is hence given by:

$$
\begin{aligned}
C^{D}(q) & =\Delta_{D} q, \\
C^{I}(q) & =\Delta_{I} q+F_{I},
\end{aligned}
$$

where $\Delta_{D} \equiv\left(1+\delta^{\frac{\phi}{\phi-1}}\right)^{\frac{\phi-1}{\phi}}$ and $\Delta_{I} \equiv(2)^{\frac{\phi-1}{\phi}}$ represent the variable costs of materials under the two modes, and $\Delta_{D}>\Delta_{I}$.

A firm that uses mode $j=D, I$ then sets its price to maximize

$$
(p-c) q(p)-C^{j}(q) \text {. }
$$

Defining $c_{D} \equiv \frac{\beta \alpha+\gamma N \bar{p}}{\gamma N+\beta}-\Delta_{D}$, we can use (3) to show that the price elasticity of demand is given by:

$$
\eta \equiv-\frac{d q(p)}{d p} \frac{p}{q}=\frac{p}{c_{D}+\Delta_{D}-p} .
$$

The profit-maximizing price of a firm with marginal labor cost $c$ choosing mode $D$, respectively $I$, is hence given by:

$$
\begin{aligned}
p^{D}(c) & =\Delta_{D}+\frac{1}{2}\left(c_{D}+c\right), \\
p^{I}(c) & =\frac{1}{2}\left(c_{D}+c+\Delta_{D}+\Delta_{I}\right) .
\end{aligned}
$$

The corresponding outputs are

$$
\begin{aligned}
q^{D}(c) & =\frac{L}{2 \beta}\left(c_{D}-c\right) \\
q^{I}(c) & =\frac{L}{2 \beta}\left(c_{D}-c+\Delta_{D}-\Delta_{I}\right)
\end{aligned}
$$

and maximized profits are given by

$$
\begin{aligned}
\pi^{D}(c) & =\frac{L}{4 \beta}\left(c_{D}-c\right)^{2}-F_{E}, \\
\pi^{I}(c) & =\frac{L}{4 \beta}\left(c_{D}-c+\Delta_{D}-\Delta_{I}\right)^{2}-F_{E}-F_{I} .
\end{aligned}
$$

Since the entry cost is sunk, only firms able to cover their marginal labor and material costs and, in case of mode $I$, the fixed cost $F_{I}$ are active in the 
market. All other firms are inactive, i.e., do not produce any output. (13) indicates that the critical value of the marginal labor cost at which a firm that has chosen mode $D$ is indifferent between being active and becoming inactive is $c_{D}$. Only mode- $D$ firms with marginal labor costs less than $c_{D}$ produce positive output. A firm that has chosen mode $I$ has a lower marginal cost of materials than a mode- $D$ firm, as $\Delta_{D}>\Delta_{I}$. Hence, as indicated by (14), such a firm would produce positive output if it had a marginal labor cost equal to $c_{D}$.

A comparison of (15) and (16) confirms that mode $I$ yields a higher variable profit than mode $D$, but also requires an additional fixed outlay of $F_{I}$. Mode $I$ is hence only attractive to firms whose output, and hence variable profit, is sufficiently big to allow them to offset $F_{I}$. These are the firms that have drawn a sufficiently high labor productivity, $1 / c$. By equating $\pi^{D}(c)$ and $\pi^{I}(c)$, we can derive the critical value of the marginal labor cost, denoted by $c_{I}$, at which a firm is indifferent between modes $D$ and $I$ :

$$
c_{I}=c_{D}+\frac{\left(\Delta_{D}-\Delta_{I}\right)}{2}-\frac{2 \beta F_{I}}{L\left(\Delta_{D}-\Delta_{I}\right)} .
$$

In order to make sure that not all entrants prefer mode $I$ to mode $D$ we have to assume that $F_{I}$ is sufficiently large. On the other hand, we do not want $F_{I}$ to be too large so that not even the most efficient firm (with $c=0$ ) would choose mode $I$. Hence we assume

$$
\frac{L}{4 \beta}\left(\Delta_{D}-\Delta_{I}\right)^{2}<F_{I}<\frac{L}{4 \beta}\left(\left(\Delta_{D}-\Delta_{I}\right)^{2}+2 c_{D}\left(\Delta_{D}-\Delta_{I}\right)\right) .
$$

This assumption, together with the quadratic form of the profit functions, ensures that the value of $c_{I}$ solving (17) is unique and lies strictly between zero and $c_{D}$. The two cut-off values of the marginal cost, $c_{D}$ and $c_{I}$, thus define three categories of firms. Firms whose labor productivity is sufficiently high $\left(c \leq c_{I}\right)$ choose mode $I$; firms whose labor productivity is in the middle range $\left(c_{I}<c \leq c_{D}\right)$ opt for mode- $D$; and firms with very low labor productivity $\left(c>c_{D}\right)$ are inactive because they are not able to cover their marginal costs.

Finally, in equilibrium the mass of entrants has to be large enough so that the expected profit of a firm at the entry stage is equal to zero:

$$
\int_{0}^{c_{I}} \pi^{I}(c) d G(c)+\int_{c_{I}}^{c_{D}} \pi^{D}(c) d G(c)+\int_{c_{D}}^{c_{M}}\left(-F_{E}\right) d G(c)=0 .
$$


In the next section we explore the equilibrium of the model, focusing on those comparative static effects that allow us to formulate testable hypotheses.

\section{Comparative Statics}

We are interested in understanding the variation in international sourcing across firms, and, in particular, how this variation is related to differences in local services availability (and thus the size of local service margins) and in the firms' labor productivity. The variables we observe at the firm level include the spending by a firm on domestic materials $(z)$, the spending on imported materials $(m)$, and the value of the firm's sales $(p q)$. We can thus investigate directly how, in equilibrium, the ratio of imported materials to sales $(m /(p q))$ changes with $\delta$ as well as with the firm's labor productivity, $1 / c$; a formal proof of the results is relegated to the Appendix.

Consider first the effect of a marginal change in $\delta$. A mode- $D$ firm's ratio of imported materials to sales can be computed using (5) and (11):

$$
\frac{m^{D}}{p^{D} q^{D}}=\frac{\delta^{\frac{1}{\phi-1}}\left(1+\delta^{\frac{\phi}{\phi-1}}\right)^{-\frac{1}{\phi}}}{\Delta_{D}+\frac{1}{2}\left(c_{D}+c\right)} .
$$

The numerator of (20) corresponds to $\mathrm{m}^{D} / q^{D}$, and it is easily verified that $d\left(m^{D} / q^{D}\right) / d \delta<0$, as an increase in $\delta$ leads to a substitution of domestic materials, $z$, for imported materials, $m$. The denominator of (20) represents $p^{D}$. A marginal increase in $\delta$ raises $p^{D}$ in two ways, namely by raising the marginal cost of materials, $\Delta_{D}$, and by lowering the price elasticity of demand, $\eta$. The effect on $\eta$ works through changes in $c_{D}$ and $\Delta_{D}$, as can be seen in (10). First, a higher $\delta$ implies a lower $c_{D}$, which boosts $\eta$. The reason why an increase in $\delta$ decreases $c_{D}$ is that it lowers the profits of mode- $D$ firms, thus forcing the least efficient mode- $D$ firms to become inactive. Second, a rise in $\delta$ increases $\Delta_{D}$, which reduces $\eta$. This second effect dominates the first so that $d \eta / d \delta<0$.

As $d p^{D} / d \delta>0$ and $d\left(m^{D} / q^{D}\right) / d \delta<0$, we have $d\left(m^{D} /\left(p^{D} q^{D}\right)\right) / d \delta<$ 0 . Thus, a marginal increase in the cost of local services reduces material imports of mode- $D$ firms relative to their sales.

In the case of mode- $I$ firms, we can use (6) and (12) to obtain:

$$
\frac{m^{I}}{p^{I} q^{I}}=\frac{(2)^{-\frac{1}{\phi}}}{\frac{1}{2}\left(c_{D}+c+\Delta_{D}+\Delta_{I}\right)} \text {. }
$$


Obviously the numerator, $m^{I} / q^{I}$, does not depend on $\delta$. But a rise in $\delta$ affects mode- $I$ firms indirectly, since, as shown above, it decreases the price elasticity of demand, $\eta$, and thus induces them to raise $p^{I}$. As a result $d\left(m^{I} /\left(p^{I} q^{I}\right)\right) / d \delta<0$, so that a marginal increase in the cost of local services also implies a smaller ratio of imported materials to sales for mode- $I$ firms. ${ }^{11}$ Mode- $I$ firms should, of course, be less affected by changes in $\delta$ than mode- $D$ firms, because their cost of material imports is independent of $\delta$, and because the price response of mode- $I$ firms is smaller: $d p^{I} / d \delta<d p^{D} / d \delta$. After all, mode- $I$ firms only raise prices in reaction to the decrease in the demand elasticity, whereas mode- $D$ firms also raise prices because they experience an increase in the marginal cost of imported materials. A sufficient condition for $m^{I} /\left(p^{I} q^{I}\right)$ to react less to a change in $\delta$ than $m^{D} /\left(p^{D} q^{D}\right)$ is for $\delta$ to be sufficiently close to 1 .

Next, consider how the ratio of imported materials to sales depends on labor productivity, $1 / c$. Since $m^{I} / q^{I}>m^{D} / q^{D}$ and $p^{I}<p^{D}$, it has to be the case that $m^{I} /\left(p^{I} q^{I}\right)>m^{D} /\left(p^{D} q^{D}\right)$. Given that mode- $I$ firms have strictly greater labor productivity than mode- $D$ firms, it follows directly that firms with a higher labor productivity import more materials relative to sales than firms with low labor productivity. This prediction can be refined still further, since, even within each mode, firms with lower labor productivity (higher $c$ ) will set higher prices than more productive firms; that is, $d\left(m^{D} /\left(p^{D} q^{D}\right)\right) / d c<0$ and $d\left(m^{I} /\left(p^{I} q^{I}\right)\right) / d c<0$. Hence the ratio of material imports to sales unambiguously rises with the firm's labor productivity.

These results can be summarized as follows:

Proposition 1 (i) A higher cost of local services lowers the ratio of imported materials to sales for low-productivity (mode-D) firms, and only indirectly for high-productivity (mode-I) firms; (ii) the ratio of imported materials to sales is increasing in a firm's labor productivity.

Proof: see Appendix.

Proposition 1 suggests three empirically testable hypotheses. First, the share of materials a firm sources from abroad relative to its sales depends negatively on the price of services (that is, positively on the availability

\footnotetext{
${ }^{11}$ Note that this indirect effect comes from the assumption that preferences are quasilinear. With CES preferences, as e.g. in Antras and Helpman (2004), prices and outputs of mode- $I$ firms would be a constant mark-up over their own marginal cost and hence would not react to changes in $\delta$.
} 
of local services). Second, this effect should be more pronounced for low productivity than high productivity firms. Third, we should observe that firms with a higher labor productivity have a higher ratio of material imports to sales. In the remainder of the paper, we investigate these empirical implications of our model using data on Irish plants.

\section{Empirical Model}

As pointed out in the previous section, we do not observe the cost of services, $\delta$, directly in our data. Instead, we use a measure of the availability of local services as a proxy. The reasoning for this proxy is that a greater availability of locally available services implies lower prices and greater service variety, which implicitly reduces the cost of using local service providers.

Based on the theoretical ideas developed in the previous sections, we estimate variants of the following empirical model:

$$
\ln (m /(p q))_{i t}=\ln (\text { services })_{j r t} \boldsymbol{\beta}_{1}+\mathbf{X}_{i t} \boldsymbol{\beta}_{2}+d_{t}+d_{j}+d_{r}+\epsilon_{i t},
$$

where $m /(p q)$ is the ratio of imported materials over sales for manufacturing plant $i$ at time $t$, and services is a vector of variables capturing the availability of services in industry $j$ and region $r$ in which plant $i$ operates. ${ }^{12} \mathbf{X}$ is a vector of control variables to account for heterogeneity at the plant, industry and regional level. We also include a full set of time, three-digit industry and region dummies $\left(d_{t}, d_{j}, d_{r}\right.$, respectively), while $\epsilon_{i t}$ denotes the final error term.

In order to measure the availability of local services, we calculate for our baseline estimation the number of services firms located in region $r$ at time $t$. This is a measure of the pool of service providers in the region in which plant $i$ is located and to which it has easy access in the domestic economy. Note that this variable has no variation across the industry dimension for different $i$ 's, as this represents the total availability of services for all firms in manufacturing industries. Hence, the implicit assumption is that all manufacturing firms in the region have access to, and use in the same intensity, the same pool of services providers. In order to show that the lack of variation along the

\footnotetext{
${ }^{12}$ In order to avoid taking the $\log$ of zero, the variable is calculated as $\ln ((m / p q)+1)$. The same goes for all other logged variables in the empirical model.
} 
industry dimension does not pose a problem for our econometric analysis, we also calculate below an alternative measure that varies across industries, based on input-output linkages between manufacturing and services sectors. This alternative is described in more detail below.

In the baseline model, we include a number of control variables at the firm level in order to be able to properly identify the effect of services availability on material imports. As such, we control for labor productivity (calculated as total wage bill per employee), a variable highlighted in our theoretical model. ${ }^{13}$ Furthermore, we include plant size (measured in terms of employment) as well as dummy variables for exporters, foreign multinationals, and domestic multinationals in our sample. These variables control for aspects of plant-level heterogeneity that have been highlighted in the recent theoretical and empirical literature. In extensions to our baseline model below, we also include further observable region-, time-, and industry-varying covariates in addition to a battery of fixed effects in order to aid identification of the coefficients on the services measures, and address endogeneity concerns.

Note that the inclusion of regional and industry dummies allows us to address some concerns about endogeneity of services availability. For example, firms may decide to locate in regions in which there are many firms in order to benefit from agglomeration economies. This would potentially introduce a correlation between the services measures and the error term. In short panels such as ours, where the location of firms does not change over time, it is a reasonable assumption that we can proxy this unobserved part of the error term using time-invariant regional dummies. To be on the safe side, we also include a set of time-varying regional variables. A similar argument could be made for unobserved effects at the industry level. If certain industries use services heavily, and if this is not fully captured by our time-varying industry variables, then this may lead to an endogeneity problem. Since, in our data, no firm switches industries, this is captured using the industry dummies.

In the first instance, we estimate our baseline model using simple OLS, allowing the error term to be clustered around plant identifiers. This estimation technique allows us to utilize both the cross section as well as time variation in our data. However, as a downside, it does not control adequately for plant-specific time-invariant unobserved effects. In order to control for such effects, we also estimate the model using a fixed effects estimator. This

\footnotetext{
${ }^{13}$ Unfortunately, we do not have capital stock or investment data, so we cannot estimate production functions to calculate total factor productivity.
} 
has the additional advantage that the plant fixed effect also allows us to control further for potential endogeneity problems in the empirical model. If there are common factors at the plant level that drive the left- as well as right-side variables in the model, these will be taken care of, as long as they are assumed to be time invariant.

\section{Description of the Data}

We use recent plant-level data from the Republic of Ireland. These data are collected by Forfás, the Irish policy and advisory board with responsibility for enterprise, trade, science, and technology. Specifically, our data source is the Annual Business Survey of Economic Impact (ABSEI), covering the period 2000 until 2004. This is an annual survey of plants with at least 10 employees, although a plant, once it is included, is generally still surveyed even if its employment level falls below the 10 employee cut-off. The survey includes plants in manufacturing as well as services. In terms of services, the focus is on internationally tradeable services; firms in other services industries are neglected. For example, in 2004, out of 538 service-sector firms in the total sample, roughly $82 \%$ are in NACE sectors 72 and 74 (computers and business services, respectively), that are directly relevant for our analysis.

This dataset, quite uniquely, provides information at the plant level on materials and services purchases, distinguishing imported and domestically procured materials and services. ${ }^{14}$ Further data available from this source that is relevant to the current paper are total sales, employment, exports, nationality of ownership, three-digit sector of production, and region of location. Within Ireland, a relatively small country, three regions are distinguished: Greater Dublin (the capital), South West \& South East, and Borders/Midlands/West (BMW). There is substantial heterogeneity in economic development across these three regions, with most of economic activity concentrated in Dublin; the South is also fairly well developed, while there is less manufacturing industry in the BMW region. As indicated, our principal measure of service availability is computed as the number of service-sector firms in each region, which changes over time.

The information on nationality of ownership allows us to establish whether a plant is an affiliate of a foreign-owned multinational. This information is

\footnotetext{
${ }^{14}$ Unfortunately, however, we do not know what type of materials or service are purchased.
} 
recorded as a binary variable indicating whether a plant is under majority ownership of a foreign owner or not. The recent literature has highlighted that identifying foreign multinationals is only one part of the picture. In order to have a complete idea about the importance of multinationals, domestic firms with affiliates abroad also need to be recognized. In 2000, Forfás, as part of the ABSEI survey, also asked firms whether they had affiliates abroad. We use this unique information and classify those domestic firms that have affiliates abroad as domestic multinationals. ${ }^{15}$

In 2004, our sample contains 1,206 manufacturing plants. Of these, 343 are affiliates of foreign multinationals, 108 are domestic multinationals, 557 are domestic exporters, and 198 are domestic without exports or foreign affiliates.

Table 1 describes the development of material imports over sales, and the main measure of local services availability, on aggregate over the time period covered in our sample. On average, Irish plants import intermediates worth about 20 percent of sales, and there are about 150 services providers in the average region. On aggregate, these figures have not changed much over the five-year period. However, the aggregate figures hide substantial heterogeneity across industries and plants, as indicated by the high standard deviation.

Table 2 provides some evidence on regional variations in our main variables of interest in 2004. While firms have on average imported material intensities of around $20 \%$, there is variation across regions in this variable. In particular, the import share is lowest in the Dublin region, which is the region with the highest number of services firms. At the same time, it is the smallest region in terms of manufacturing firms. In order to investigate the link between imported materials and services at the firm level, it therefore appears necessary to control for such differences in regional characteristics.

In Table 3, we depict differences across industries. The first columns show means and standard deviations of the imported-materials-to-sales ratio by two digit industry for the year 2004. The means range from 12 percent (NACE 15-Food) to 27 percent (NACE 34-Transport Equipment). The subsequent columns also show summary statistics for the number of services firms in the region. Again, the statistics show differences across industries

\footnotetext{
${ }^{15}$ Girma et al. (2004) use this data to investigate productivity differentials between domestic multinationals, exporters, and purely domestic firms. There are, to the best of our knowledge, no other studies that have been able to identify domestic multinationals in Ireland in large micro level data sets.
} 
and firms. For these summary statistics there is a negative raw pairwise correlation between the ratio of imported materials to sales and the number of services firms. However, the correlation coefficients are not statistically significant. This suggests again that it is important to control for plant level heterogeneity in order to uncover the relationship between material imports and services availability at the plant level.

Table 4 shows that, as commonly found in the literature, plant-level heterogeneity matters for our analysis. The table reports coefficients from simple pooled OLS regressions of selected plant-level characteristics on dummies for exporting status, foreign multinational, and domestic multinational indicators. These regressions are estimated separately for the three regions. As dependent variables, we employ the ratio of imported materials over sales, employment size and labor productivity. The latter two are reported here to link our paper to the large literature on firm level heterogeneity. Results show that, as expected, there are premia to firm status. We find the standard size and productivity premia for exporters and multinationals. More related to our topic of interest, we also find that multinationals, exporters and, in one regression, domestic multinationals tend to import more materials than domestic firms. The finding that exporters and multinationals have higher material import ratios is consistent with our theoretical model, which predicts that this ratio should be higher for high-productivity establishments.

\section{Empirical Results}

We now turn to the estimation of our empirical model described in Section 4. Table 5 provides results for our baseline model, which includes time, region and industry dummies and is estimated using OLS. Hence, this estimation approach allows us to use the variation across establishments and time to identify the effect of services availability on the ratio of material imports to sales. Column (1) presents the most basic version of the empirical model, including the measure of the availability of services firms in the same region as plant $i$. The results show that, controlling for unobserved heterogeneity at the industry and region level, greater services availability is associated with a higher ratio of materials imports to sales by manufacturing establishments. This is in line with our theoretical model, whereby services are needed to facilitate the successful import of materials. While we also find a positive coefficient on labor productivity, as predicted by the model, this is statistically 
insignificant in the baseline specification.

One aspect we need to take into account is the empirical importance of multinationals also for the provision of services inputs. It could be the case that our results not so much reflect the importance of the domestic provision of services (i.e., by local firms) but just pick up the importance of multinationals for linking up firms with suppliers abroad. Our data allow us to look into this in more detail. We calculate our service availability measures separately for domestic establishments and foreign multinationals and include these as separate regressors in the model. The results, reported in column (2), show that it is indeed the availability of domestic providers of services, rather than just the presence of foreign multinational service firms, that matters in the regression.

The results in columns (3) to (6) allow us to dig deeper into plant level heterogeneity. We control for establishment status by including dummies for foreign multinationals, domestic multinationals, and exporters. Furthermore, we have run the regression separately for domestic multinationals, foreign multinationals and domestic plants, and report the results in the respective columns. This also links our analysis back to the theoretical model, which shows that there are differences in the importance of local services availability for mode- $I$ and - $D$ firms. Multinationals are more likely to internalize service provision within their company structure, so are likely to be mode- $I$ firms.

What is especially noteworthy in the results is that the availability of local service providers matters only for domestic establishments. Domestic or foreign multinationals, by contrast, are not affected by the thickness of services at all. This is consistent with the theoretical model, assuming that multinationals are more likely to be internalizers of services provision. Moreover, this finding squares well with the observation in the data that of all manufacturing firms, multinationals import services most intensively. ${ }^{16}$ We also find that the coefficient on productivity is still statistically insignificant for domestic multinationals and purely domestic firms, but negative and significant for foreign multinationals. However, this result is difficult to interpret, since it may reflect other aspects of plant heterogeneity that are not controlled for. It should also be kept in mind that the coefficient on labor productivity is conditional on other covariates. In particular, the model includes size, which

\footnotetext{
${ }^{16}$ Some fraction of the imported intermediates by multinationals will be intra-firm trade. By definition, stand-alone firms are not involved in intra-firm trade. Our data do not allow us to distinguish between intra-firm and arms' length trade of multinationals. However, anecdotal evidence suggest that intra-firm trade is significant for services.
} 
is likely to be correlated with productivity (but does not feature in our theoretical model). Note that size consistently returns a positive coefficient, i.e., larger plants have higher ratios of imported materials.

Overall, our baseline results are thus in line with the theoretical idea that services are needed to "grease the wheels of commerce." In what follows we check how robust our baseline results are to changes in the specification of the model. For instance, the availability of services may affect not only imports of materials but also exports of firms, which is a feature not captured by our theoretical model. In order to take this empirical possibility into account, we include only exporters in our regression sample. In Table 6 we replicate the equivalent of Table 5 but only for exporters. As can be seen, the result indicating the importance of services availability for domestic establishments still holds.

One may, of course, be worried about endogeneity of our service availability measures, which may bias our results obtained thus far. We attempt to deal with endogeneity in the further analysis. First, as pointed out above, we argue that in a short panel plant fixed effects, which also capture time invariant industry and regional characteristics, take care of this to a large extent. Table 7 presents the results of fixed effects estimations. These show that services availability matters in the same way as before. We also find, as alluded to above, that once we control for unobserved time-invariant plantspecific effects, the coefficient on productivity turns positive and statistically significant for domestic firms, but remains statistically insignificant for multinationals (domestic or foreign).

Another concern with our estimation thus far is that the services measure is region-specific, and may therefore just pick up any region specific timevarying characteristic. In order to alleviate this concern, we include further time-varying variables at the region and industry level, which may capture any potential correlation between our thickness measure and the error term. At the regional level, we include the number of manufacturing firms (foreign and domestic) as well as total sales in the region. The former is included in order to address the possibility that the service availability measure just captures general agglomeration effects, which may influence firms' sourcing decisions. The second measure is included in order to capture the size of a region. At the industry level, we control for the service intensity of the industry (value of total services inputs over total sales in the industry) as well as the intensity with which the industry uses locally sourced services (value of locally sourced services over total services inputs). These measures 
allow us to control for heterogeneity in the use and sourcing of services inputs in different industries.

The results are reported in Table 8 . Some points are particularly noteworthy. First, the result that the availability of local services firms matters for sourcing decisions of domestic establishments holds. Second, we now find that the availability of foreign multinational services firms affects the sourcing decisions of domestic multinationals positively. However, this effect, as shown below, is not robust to further changes to the model; hence, we do not place much emphasis on it.

Before we deal further with any robustness checks, we come back to the theoretical prediction of the model. One hypothesis from Proposition 1 that we have not considered yet is that (low productivity) mode- $D$ firms should react more strongly to changes in the availability of services providers than (high productivity) mode- $I$ firms. In order to investigate this empirically, we interact the service thickness variables with plant level labor productivity. The results, estimated using a fixed effects technique, are presented in Table 9. Note that, for domestic establishments at least, results are in line with our hypothesis. The coefficient on the availability of local services remains positive and statistically significant, and the interaction of this variable is negative, implying that the positive effect of services availability is smaller for firms with higher labor productivity. However, the coefficient on the interaction term is imprecisely estimated. The lack of statistical significance may reflect that we are asking too much of our service variable, which, as discussed above, only varies over three regions and over time. Interacting this with labor productivity generates a variable that is highly correlated with productivity on its own; the exercise may ask too much of the data.

In order to alleviate this problem, we calculate an alternative service availability measure that also varies across industries. This, furthermore, allows us to deal with a possible concern that the services measure employed just picks up regional characteristics. In order to come up with the alternative, we make use of the Irish input-output table for 2000 which allows us to trace input links between two-digit manufacturing and services sectors. We calculate what may be termed an "effective availability" measure by multiplying the number of services firms in a region and two digit service sector by the input use coefficient of the two digit service in manufacturing industry $j$, and summing over region and industry $j$. The exact definition of this variable is relegated to the Appendix.

Using this alternative measure and re-estimating the model used in Table 
9 shows, in Table 10, similar results. ${ }^{17}$ For domestic establishments, we find that the availability of local services matters. The coefficient on the interaction term is negative as before, but not statistically significant. Labor productivity on its own is positively related to the ratio of material imports to sales, as expected, and is statistically significant. Furthermore, as before, we do not find any evidence that the availability of local services matters for domestic or foreign multinationals in Ireland.

We now return to a discussion of endogeneity. Arguably, the inclusion of plant fixed effects as well as of a number of time-varying firm, industry, and regional variables is likely to be sufficient to alleviate such concerns, especially in our short panel. Still, we proceed further and test whether, conditional on the inclusion of all these covariates, the service availability measures are likely to be endogenous in our empirical model. To do so, we re-estimate the models presented in Table 10 using an IV estimator employing twice lagged levels and differences of the variables as instruments. The estimations are reported in Table 11. Note that the overidentification tests suggest that these are valid instruments, while the first stage F-tests suggest strongly that they are also relevant. While the signs are the same as in Tables 9 and 10, there are differences in statistical significance levels. For domestic firms, we now find a statistically significant positive coefficient on the interaction term, as we would expect. Moreover, we find that the availability of services provided by multinationals matters for domestic firms. Furthermore, there is now evidence that imports of materials by foreign multinationals react to changes in the availability of locally provided services. However, note that, importantly, the Durbin-Wu-Hausman tests do not allow us to reject the null hypothesis of exogeneity of regressors. Hence, we prefer the FE estimates presented in Table 10 to the IV estimates.

\section{Conclusion}

The paper examined whether services grease the wheels of international commerce in the sense that they facilitate the ongoing process of international fragmentation of production that has received ample attention under the heading of 'outsourcing' and 'off-shoring'. Specifically we wanted to examine what effect services have on off-shoring at the micro-level. For this purpose,

\footnotetext{
${ }^{17}$ Note that, when estimating the model in Table 8, using the alternative measure we also get similar results. These estimations are not reported here, however, to save space.
} 
we used firm-level data from the Republic of Ireland to investigate whether the availability of local services induces manufacturing firms to source more material inputs from abroad, and whether this effect differed across firms of different size or labor productivity and different status as national or multinational firm.

To guide the empirics, we sketched a monopolistic competition model with heterogeneous firms. In the model, firms source intermediate goods both locally and internationally. Imports of materials require services that can be obtained either from local third-party providers, or, alternatively, be imported or produced by the firm itself. Our empirics generally bear out the predictions of the model: (i) greater availability of services in the firm's home region leads to a higher ratio of imported materials to sales; and (ii) larger or more productive firms in an industry have a greater material-imports-tosales ratio. Moreover, it turns out that the availability of services is especially important for local Irish firms but not for multinationals, which suggests that multinationals are able to internalize the provision of their services and/or rely on imported services. The general conclusion of the paper hence is that services indeed grease the wheels of international commerce.

\section{Appendix}

\subsection{Proof of Proposition 1}

The proof has four parts. First, we show that $d c_{D} / d \delta<0$. Using the Pareto distribution, the zero-profit condition (19) can be rewritten as

$$
\begin{aligned}
\frac{c_{D}^{k+2}}{(k+1)(k+2)}+\left(\Delta_{D}-\Delta_{I}\right) c_{I}^{k}\left(\frac{\Delta_{D}-\Delta_{I}}{2}+c_{D}\right. & \left.-\frac{k c_{I}}{k+1}\right) \\
& -\frac{2 \beta}{L}\left(c_{M}^{k} F_{E}+F_{I} c_{I}^{k}\right)=0
\end{aligned}
$$

Total differentiation yields

$$
\frac{d c_{D}}{d \delta}=-\frac{c_{I}^{k}\left(c_{D}+\Delta_{D}-\Delta_{I}-\frac{k c_{I}}{k+1}\right)}{\frac{c_{D}^{k+1}}{(k+1)}+\left(\Delta_{D}-\Delta_{I}\right) c_{I}^{k}} \frac{d \Delta_{D}}{d \delta}<0
$$

since $\frac{c_{D}^{k+1}}{(k+1)}+\left(\Delta_{D}-\Delta_{I}\right) c_{I}^{k}=2 c_{D}^{k}\left(\Delta_{D}+c_{D}-\bar{p}\right)>0$ and $\Delta_{D}-\Delta_{I}+c_{D}-\frac{k c_{I}}{k+1}>0$ due to $\Delta_{D}>\Delta_{I}, c_{D}>c_{I}$ and $k<1+k$. 
Second, we demonstrate that $\left|\frac{d c_{D}}{d \delta}\right|<\frac{d \Delta_{D}}{d \delta}$. Rewriting and manipulating (22), we obtain

$$
\frac{d c_{D}}{d \delta}=-\frac{(1+k)\left(\Delta_{D}-\Delta_{I}\right)+c_{D}+k\left(c_{D}-c_{I}\right)}{(1+k)\left(\Delta_{D}-\Delta_{I}\right)+\frac{c_{D}^{1+k}}{c_{I}^{k}}} \frac{d \Delta_{D}}{d \delta} .
$$

Thus, $\left|\frac{d c_{D}}{d \delta}\right|<\frac{d \Delta_{D}}{d \delta}$ if $1+k\left(1-\frac{c_{I}}{c_{D}}\right)<\frac{c_{D}^{k}}{c_{I}^{k}}$. When $k=1$, this inequality reduces to $\left(c_{D}-c_{I}\right)^{2}>0$. When $k>1$, the RHS of the above inequality increases faster than the LHS.

Third, we show that $d p^{D} / d \delta>d p^{I} / d \delta>0$. Note that

$$
\begin{aligned}
\frac{d p^{D}}{d \delta} & =\frac{1}{2}\left(\frac{d c_{D}}{d \delta}+2 \frac{\Delta_{D}}{d \delta}\right) \\
\frac{d p^{I}}{d \delta} & =\frac{1}{2}\left(\frac{d c_{D}}{d \delta}+\frac{\Delta_{D}}{d \delta}\right) .
\end{aligned}
$$

Hence the result follows immediately from $\frac{d c_{D}}{d \delta}<0, \frac{\Delta_{D}}{d \delta}>0$, and $\left|\frac{d c_{D}}{d \delta}\right|<\frac{d \Delta_{D}}{d \delta}$.

Fourth, we derive a sufficient condition for

$$
\left|\frac{d}{d \delta}\left(\frac{m^{D}}{q^{D} p^{D}}\right)\right|>\left|\frac{d}{d \delta}\left(\frac{m^{I}}{q^{I} p^{I}}\right)\right| .
$$

We have

$$
\begin{aligned}
\frac{d}{d \delta}\left(\frac{m^{D}}{q^{D} p^{D}}\right) & =-\frac{m^{D}}{q^{D}\left(p^{D}\right)^{2}} \frac{d p^{D}}{d \delta}+\frac{1}{p^{D}} \frac{d\left(m^{D} / q^{D}\right)}{d \delta} \\
\frac{d}{d \delta}\left(\frac{m^{I}}{q^{I} p^{I}}\right) & =-\frac{m^{I}}{q^{I}\left(p^{I}\right)^{2}} \frac{d p^{I}}{d \delta}
\end{aligned}
$$

Given that $d p^{D} / d \delta>d p^{I} / d \delta>0, p^{D}>p^{I}, \frac{m^{D}}{q^{D} p^{D}}<\frac{m^{I}}{q^{I} p^{I}}$, and $d\left(m^{D} / q^{D}\right) / d \delta<$ 0 , a sufficient condition for $\left|d\left(m^{D} /\left(p^{D} q^{D}\right)\right) / d \delta\right|>\left|d\left(m^{I} /\left(p^{I} q^{I}\right)\right) / d \delta\right|$ is that $\frac{m^{D}}{q^{D} p^{D}}$ is close enough to $\frac{m^{I}}{q^{I} p^{I}}$, which is the case if $\delta$ is sufficiently close to 1 .

\subsection{Definition of the Alternative Services Availability Measure}

To calculate the alternative services availability measure, we use our plantlevel information on the location and two-digit sector of services firms. Hence, 
we are able to calculate for each region $r$ the number of services firms in service sector $s, n_{s}$. From the Irish input-output table for 2000, we use the input coefficients $a_{j s}$, which give us the amount of inputs from service sector $s$ used in manufacturing industry $j$ as percentage of output of industry $j$.

Our alternative measure is then calculated as an "effective services availability",

$$
\text { alternative_services }_{j r t}=\left(\sum_{s} a_{j s} * n_{s t}\right) / n_{m t}
$$

We scale this variable using the number of manufacturing firms in region $r, n_{m}$. This allows us to deal with another concern one may have with the initial measure, namely, that it reflects characteristics related to the size of manufacturing activity in the region.

Table A1 presents some summary statistics on the variation of the effective availability measure within and across regions. Note that the absolute value of the measure is intrinsically meaningless, what matters is the variation. We see that, as for the standard thickness measure, Dublin has the highest values and BMW the lowest. Note, however, that now we also have substantial variation within region in these measures, as indicated by the standard deviation.

\section{References}

[1] Aitken, B.J. and A.E. Harrison, 1999, Do Domestic Firms Benefit from Direct Foreign Investment? Evidence from Venezuela, American Economic Review 89, 605-618.

[2] Antras, Pol and Elhanan Helpman, 2004, Global Sourcing, Journal of Political Economy 112 (3), 552-580.

[3] Bas, Maria, 2008, Foreign Competition, Imported Inputs and Firms' Decisions, mimeo.

[4] Breinlich, Holger and Chiara Criscuolo, 2009, International Trade in Services: A Portrait of Importers and Exporters, mimeo.

[5] Corbett, Michael, 2004, The Outsourcing Revolution: Why It Makes Sense and How To Do It Right, Dearborn Trade Publishing. 
[6] Deardorff, Alan, 2001, The International Provision of Trade Services, Trade and Fragmentation, Review of International Economics 9 (2), 233-248.

[7] Dedrick, Jason, Kenneth L. Kraemer and Greg Linden, 2009, Who Profits from Innovation in Global Value Chains?: A Study of the iPod and notebook PCs, Industrial and Corporate Change, forthcoming.

[8] Feenstra, Robert C., 1998, Integration of Trade and Disintegration of Production in the Global Economy, Journal of Economic Perspectives $12,31-50$.

[9] Francois, Joseph, 1990, Trade in Producer Services and Returns due to Specialization under Monopolistic Competition, Canadian Journal of Economics 23 (1), 109-124.

[10] Francois, Joseph and Bernard Hoekman, 2009, Services Trade and Policy, Working Paper, Economics Department Linz.

[11] Gachon, Gerard and Christina Terwiesch, 2009, Matching Supply and Demand: An Introduction Operations Management, McGraw-Hill.

[12] Girma, Sourafel, Holger Görg and Eric Strobl, 2004, Exports, International Investment, and Plant Performance: Evidence from a Nonparametric Test, Economics Letters, 83, 317-324.

[13] Golub, Stephen, Jones, Ronald and Henryk Kierzkowski, 2007, Globalization and Country-Specific Service Links, Journal of Economic Policy Reform 10(2), 63-88.

[14] Helpman, Elhanan, 2006, Trade, FDI and the Organization of the Firm, Journal of Economic Literature, 44 (3), 589-630.

[15] Hummels, David L., Jun Ishii and Kei-Mu Yi, 2001, The Nature of Growth of Vertical Specialization in World Trade, Journal of International Economics 54(1), 75-96.

[16] Jones, Ronald and Henryk Kierzkowski, 1990, The role of Services in Production and International Trade: A Theoretical Framework, in: Ronald Jones and Anne Krueger (eds.), The Political Economy of International Trade: Essays in Honor of Robert E. Baldwin, Cambridge, MA, Blackwell, 31-48. 
[17] Long, Ngo V., Raymond Riezman and Antoine Soubeyran, 2005, Fragmentation and Services, North American Journal of Economics and Finance 16 (1), 137-152.

[18] Melitz, Marc, 2003. The Impact of Trade on Intra-Industry Reallocations and Aggregate Industry Productivity, Econometrica 71, 1695-1725.

[19] Melitz, Marc J. and Gianmarco I.P. Ottaviano, 2008, Market Size, Trade and Productivity, Review of Economic Studies 75(1), 295-316.

[20] OECD, 2009, OECD Factbook: Economic, Environmental and Social Statistics. http://lysander.sourceoecd.org/vl=8004690/cl=33/nw $=1 /$ rpsv/factbook2009/03/01/03/index.htm

[21] Oldenski, Linda, 2009, Exports vs. FDI: A Task-Based Framework for Comparing Manufacturing and Services, working paper UCSD.

[22] Raff, Horst and Nicolas Schmitt, 2009. Imports, Pass-Through, and the Structure of Retail Markets, Kiel Working Paper 1556 (http://www.ifw-members.ifw-kiel.de/publications/imports-passthrough-and-the-structure-of-retail-markets/kwp_1556).

[23] Sweeney, E, C-M Wagner and B. Huber, 2008, Supply Chain Management Diffusion Among Firms in the Republic of Ireland, International Journal of Logistics: Research and Applications 11(5), 347-358.

[24] Yi, Kei-Mu, 2003, Can Vertical Specialization Explain the Growth of World Trade? Journal of Political Economy 111(1), 52-102. 
Table 1: Development of (Imported materials / Sales) and service availability measure over time

\begin{tabular}{|l|l|l|l|r|}
\hline Year & $\begin{array}{l}\text { Imported } \\
\text { materials } / \\
\text { Sales }\end{array}$ & & $\begin{array}{l}\text { Services } \\
\text { firm } \\
\text { availability }\end{array}$ & \\
\hline & mean & Std.dev. & mean & Std.dev. \\
\hline 2000 & 0.212 & 0.147 & 135.23 & 1.71 \\
\hline 2001 & 0.200 & 0.151 & 150.96 & 1.77 \\
\hline 2002 & 0.188 & 0.149 & 163.20 & 1.73 \\
\hline 2003 & 0.181 & 0.147 & 175.21 & 1.68 \\
\hline 2004 & 0.190 & 0.146 & 149.16 & 1.64 \\
\hline
\end{tabular}

Notes:

- Services firm availability is defined as number of services firms in region $r$ at time $t$.

Table 2: Summary statistics across regions, 2004

\begin{tabular}{|l|l|l|l|}
\hline Region & Dublin & South West \& East & Borders/Midlands/West \\
\hline $\begin{array}{l}\text { Imported materials / } \\
\text { Sales }\end{array}$ & 0.182 & 0.210 & 0.200 \\
\hline & $(0.172)$ & $(0.178)$ & $(0.169)$ \\
\hline \# of Services firms & 289 & 174 & 75 \\
\hline $\begin{array}{l}\text { \# of MNC services } \\
\text { firms }\end{array}$ & 72 & 64 & 20 \\
\hline $\begin{array}{l}\text { \# of Domestic services } \\
\text { firms }\end{array}$ & 217 & 110 & 55 \\
\hline & & & 378 \\
\hline $\begin{array}{l}\text { \# of manufacturing } \\
\text { firms }\end{array}$ & 242 & 586 & \\
\hline
\end{tabular}

Notes:

- Table reports means and standard deviations in parentheses.

- Imported materials / sales is defined as total value of imported materials over total value of sales. 
Table 3: Variation of (Imported materials / Sales) and service availability measure over sectors, year 2004

\begin{tabular}{|c|c|c|c|c|}
\hline NACE Description & $\begin{array}{l}\text { Imported } \\
\text { materials } \\
\text { / Sales }\end{array}$ & & $\begin{array}{l}\text { Services } \\
\text { firm } \\
\text { availability }\end{array}$ & \\
\hline & mean & Std.dev. & mean & Std.dev. \\
\hline Food \& Beverages & 0.119 & 0.128 & 151.11 & 1.69 \\
\hline Tobacco & 0.189 & 0.144 & 129.15 & 2.03 \\
\hline Textiles & 0.264 & 0.134 & 128.38 & 1.71 \\
\hline Apparel & 0.273 & 0.131 & 159.49 & 1.82 \\
\hline Leather & 0.221 & 0.126 & 123.72 & 1.82 \\
\hline Wood products & 0.152 & 0.140 & 115.12 & 1.65 \\
\hline Pulp \& paper & 0.226 & 0.163 & 199.94 & 1.68 \\
\hline Publishing \& printing & 0.143 & 0.135 & 222.29 & 1.69 \\
\hline Coke \& petrol & 0.232 & 0.071 & 75.19 & 1.09 \\
\hline Chemicals & 0.238 & 0.142 & 184.56 & 1.64 \\
\hline Rubber \& plastic & 0.243 & 0.151 & 135.10 & 1.71 \\
\hline Non-metallic minerals & 0.144 & 0.128 & 141.74 & 1.73 \\
\hline Basic metals & 0.203 & 0.182 & 161.42 & 1.59 \\
\hline Fabricated metals & 0.180 & 0.150 & 157.28 & 1.65 \\
\hline Machinery & 0.208 & 0.145 & 149.90 & 1.67 \\
\hline Office machinery & 0.230 & 0.184 & 170.89 & 1.78 \\
\hline Electrical machinery & 0.230 & 0.162 & 157.43 & 1.73 \\
\hline Radio \& communications & 0.224 & 0.161 & 177.15 & 1.62 \\
\hline Medical \& optical instruments & 0.203 & 0.133 & 145.33 & 1.68 \\
\hline Vehicles & 0.265 & 0.119 & 124.21 & 1.57 \\
\hline Other transport equipment & 0.258 & 0.136 & 215.94 & 1.60 \\
\hline Other manufacturing & 0.186 & 0.126 & 146.64 & 1.79 \\
\hline
\end{tabular}


Table 4: Premia for exporters, foreign multinationals and Irish multinationals

\begin{tabular}{|l|l|l|l|l|l|l|l|l|l|}
\hline & $(1)$ & $(2)$ & $(3)$ & $(4)$ & $(5)$ & $(6)$ & $(7)$ & $(8)$ & $(9)$ \\
\hline Region & Dublin & South & Border & Dublin & South & Border & Dublin & South & Border \\
\hline & $\begin{array}{l}\text { ln(imports } \\
\text { / sales) }\end{array}$ & $\begin{array}{l}\text { ln(imports } \\
\text { / sales) }\end{array}$ & $\begin{array}{l}\text { ln(imports } \\
\text { / sales) }\end{array}$ & $\begin{array}{l}\text { ln(employ } \\
\text { ment) }\end{array}$ & $\begin{array}{l}\text { ln(employ } \\
\text { ment) }\end{array}$ & $\begin{array}{l}\text { ln(employ } \\
\text { ment) }\end{array}$ & $\begin{array}{l}\text { ln(producti } \\
\text { vity) }\end{array}$ & $\begin{array}{l}\text { ln(producti } \\
\text { vity) }\end{array}$ & $\begin{array}{l}\text { ln(producti } \\
\text { vity) }\end{array}$ \\
\hline $\begin{array}{l}\text { Foreign MNC } \\
\text { dummy }\end{array}$ & 0.044 & 0.051 & 0.078 & 0.995 & 1.053 & 0.854 & 0.300 & 0.260 & 0.238 \\
\hline & $(0.019)^{* *}$ & $(0.012)^{* * *}$ & $(0.017)^{* * *}$ & $(0.176)^{* * *}$ & $(0.112)^{* * *}$ & $(0.120)^{* * *}$ & $(0.052)^{* * *}$ & $(0.033)^{* * * *}$ & $(0.038)^{* * *}$ \\
\hline $\begin{array}{l}\text { Domestic } \\
\text { MNC dummy }\end{array}$ & 0.028 & 0.064 & 0.048 & 0.158 & 0.414 & 0.504 & 0.039 & 0.027 & 0.122 \\
\hline & $(0.017)^{*}$ & $(0.012)^{* * *}$ & $(0.015)^{* * *}$ & $(0.142)$ & $(0.088)^{* * *}$ & $(0.101)^{* * *}$ & $(0.049)$ & $(0.035)$ & $(0.052)^{* *}$ \\
\hline $\begin{array}{l}\text { Exporter } \\
\text { dummy }\end{array}$ & 0.021 & 0.023 & 0.036 & 0.642 & 0.557 & 0.894 & 0.043 & 0.091 & 0.088 \\
\hline & $(0.020)$ & $(0.015)$ & $(0.018)^{*}$ & $(0.136)^{* * *}$ & $(0.142)^{* * *}$ & $(0.139)^{* * *}$ & $(0.049)$ & $(0.041)^{* *}$ & $(0.052)^{*}$ \\
\hline Obs. & 1137 & 2610 & 1731 & 1137 & 2610 & 1731 & 1137 & 2610 & 1731 \\
\hline R-squared & 0.29 & 0.25 & 0.28 & 0.38 & 0.35 & 0.32 & 0.36 & 0.28 & 0.27 \\
\hline
\end{tabular}

Simple OLS regression of dependent variable on foreign, domestic multinational and export dummies. Regression includes constant term, three digit industry and time dummies.

Imports / sales is defined as total value of imported materials over total value of sales.

Robust standard errors, clustered around plant identifier, in parentheses.

* significant at $10 \%$;* significant at $5 \%$; ** significant at $1 \%$. 
Table 5: Baseline model for all firms

Dependent variable: $\ln ($ Imported materials / Sales)

\begin{tabular}{|c|c|c|c|c|c|c|}
\hline & $(1)$ & $(2)$ & (3) & (4) & $(5)$ & $(6)$ \\
\hline & all & All & All & ODI & Foreign & Domestic \\
\hline \multirow{2}{*}{$\begin{array}{l}\text { Services firm } \\
\text { availability }\end{array}$} & 0.129 & & & & & \\
\hline & $(0.045)^{* * *}$ & & & & & \\
\hline \multirow{2}{*}{$\begin{array}{l}\text { Foreign MNC services } \\
\text { firm availability }\end{array}$} & & 0.043 & 0.050 & 0.221 & 0.043 & 0.013 \\
\hline & & $(0.043)$ & $(0.042)$ & $(0.152)$ & $(0.080)$ & $(0.053)$ \\
\hline \multirow{2}{*}{$\begin{array}{l}\text { Domestic services firm } \\
\text { availability }\end{array}$} & & 0.087 & 0.084 & 0.082 & 0.026 & 0.085 \\
\hline & & $(0.031)^{* * *}$ & $(0.031)^{* * *}$ & $(0.091)$ & $(0.065)$ & $(0.039) * *$ \\
\hline \multirow[t]{2}{*}{ Labor productivity } & 0.003 & 0.003 & -0.018 & -0.017 & -0.049 & -0.005 \\
\hline & $(0.007)$ & $(0.007)$ & $(0.007)^{* * *}$ & $(0.031)$ & $(0.018)^{* * *}$ & $(0.008)$ \\
\hline \multirow[t]{2}{*}{ Dummy domestic MNC } & & & 0.020 & & & \\
\hline & & & $(0.010)^{* *}$ & & & \\
\hline \multirow[t]{2}{*}{ Dummy foreign MNC } & & & 0.051 & & & \\
\hline & & & $(0.009)^{* * *}$ & & & \\
\hline \multirow[t]{2}{*}{ Dummy exporter } & & & 0.051 & 0.179 & 0.047 & 0.051 \\
\hline & & & $(0.008) * * *$ & $(0.050) * * *$ & $(0.032)$ & $(0.009) * * *$ \\
\hline \multirow[t]{2}{*}{ Firm size } & & & 0.008 & 0.030 & 0.001 & 0.010 \\
\hline & & & $(0.003)^{* * *}$ & $(0.010) * * *$ & $(0.006)$ & $(0.004) * * *$ \\
\hline Observations & 5478 & 5478 & 5478 & 466 & 1527 & 3485 \\
\hline R-squared & 0.16 & 0.16 & 0.20 & 0.38 & 0.19 & 0.21 \\
\hline
\end{tabular}

Regressions with 3-digit industry and region dummies.

Robust standard errors, clustered around firm identifier, in parentheses.

$*$ significant at $10 \%$; ** significant at 5\%; *** significant at $1 \%$.

Regressions include constant term.

Services firm availability is defined as number of services firms in region $r$ at time $t$.

Foreign MNC services firm availability and domestic services firm availability are defined as number of foreign and domestic services firms in region $r$ at time $t$, respectively. 
Table 6: Baseline model for exporters only

Dependent variable: $\ln ($ Imported materials / Sales)

\begin{tabular}{|c|c|c|c|c|}
\hline & $(1)$ & $(2)$ & (3) & $(4)$ \\
\hline & All & ODI & Foreign & Domestic \\
\hline \multicolumn{5}{|l|}{$\begin{array}{l}\text { Services firm } \\
\text { availability }\end{array}$} \\
\hline \multirow{2}{*}{$\begin{array}{l}\text { Foreign MNC services } \\
\text { firm availability }\end{array}$} & 0.056 & 0.239 & 0.050 & 0.019 \\
\hline & $(0.047)$ & $(0.152)$ & $(0.082)$ & $(0.065)$ \\
\hline \multirow{2}{*}{$\begin{array}{l}\text { Domestic services firm } \\
\text { availability }\end{array}$} & 0.092 & 0.090 & 0.031 & 0.103 \\
\hline & $(0.036) * *$ & $(0.092)$ & $(0.070)$ & $(0.049) * *$ \\
\hline \multirow[t]{2}{*}{ Labor productivity } & -0.025 & -0.018 & -0.048 & -0.009 \\
\hline & $(0.009) * * *$ & $(0.032)$ & $(0.018)^{* * *}$ & $(0.010)$ \\
\hline \multirow[t]{2}{*}{ Dummy domestic MNC } & 0.025 & & & \\
\hline & $(0.011)^{* *}$ & & & \\
\hline \multirow[t]{2}{*}{ Dummy foreign MNC } & 0.051 & & & \\
\hline & $(0.010) * * *$ & & & \\
\hline \multirow[t]{2}{*}{ Firm size } & 0.009 & 0.033 & 0.002 & 0.010 \\
\hline & $(0.003) * *$ & $(0.010) * * *$ & $(0.006)$ & $(0.004) * *$ \\
\hline Observations & 4496 & 454 & 1469 & 2573 \\
\hline R-squared & 0.19 & 0.37 & 0.18 & 0.22 \\
\hline
\end{tabular}

Regressions with 3-digit industry and region dummies.

Robust standard errors, clustered around firm identifier, in parentheses.

$*$ significant at $10 \%$; ** significant at 5\%; *** significant at $1 \%$.

Regressions include constant term.

For definition of service availability measures see Table 5. 
Table 7: Baseline model with firm fixed effects for exporters only

Dependent variable: $\ln ($ Imported materials / Sales)

\begin{tabular}{|l|l|l|l|}
\hline & $(1)$ & $(2)$ & $(3)$ \\
\hline & ODI & Foreign & Domestic \\
\hline $\begin{array}{l}\text { Foreign MNC services } \\
\text { firm availability }\end{array}$ & 0.254 & -0.078 & 0.010 \\
\hline & $(0.102)^{* *}$ & $(0.054)$ & $(0.039)$ \\
\hline $\begin{array}{l}\text { Domestic services firm } \\
\text { availability }\end{array}$ & 0.026 & -0.009 & 0.093 \\
\hline & $(0.065)$ & $(0.040)$ & $(0.028)^{* * *}$ \\
\hline Labor productivity & -0.020 & 0.010 & 0.016 \\
\hline & $(0.022)$ & $(0.013)$ & $(0.008)^{*}$ \\
\hline Firm size & -0.039 & 0.037 & 0.012 \\
\hline & $(0.025)$ & $(0.010)^{* * *}$ & $(0.007)^{*}$ \\
\hline Observations & 454 & 1469 & 2573 \\
\hline \# of firms & 205 & 482 & 966 \\
\hline R-squared & 0.06 & 0.03 & 0.02 \\
\hline
\end{tabular}

Regressions with firm fixed effects.

R-squared for regression on within transformed variables, any impact of time invariant explanatory variables is purged.

Standard errors in parentheses.

* significant at $10 \%$; ** significant at 5\%; *** significant at $1 \%$.

Regressions include constant term.

For definition of availability measures see Table 5 . 
Table 8: Extended model with additional covariates, for exporters only

Dependent variable: $\ln ($ Imported materials / Sales)

\begin{tabular}{|l|l|l|l|}
\hline & $(1)$ & $(2)$ & $(3)$ \\
\hline & ODI & Foreign & Domestic \\
\hline Foreign MNC services firm availability & 0.241 & -0.088 & 0.009 \\
\hline & $(0.106)^{* *}$ & $(0.060)$ & $(0.042)$ \\
\hline Domestic services firm availability & 0.098 & -0.024 & 0.103 \\
\hline & $(0.080)$ & $(0.045)$ & $(0.033)^{* * *}$ \\
\hline Labor productivity & -0.025 & 0.016 & 0.017 \\
\hline & $(0.022)$ & $(0.013)$ & $(0.008)^{* *}$ \\
\hline Firm size & -0.033 & 0.039 & 0.013 \\
\hline & $(0.025)$ & $(0.010)^{* * *}$ & $(0.007)^{*}$ \\
\hline Industry total services intensity & -0.016 & 0.005 & -0.001 \\
\hline & $(0.022)$ & $(0.009)$ & $(0.008)$ \\
\hline Industry local services intensity & 0.164 & -0.143 & -0.028 \\
\hline & $(0.088)^{*}$ & $(0.042)^{* * *}$ & $(0.040)$ \\
\hline $\begin{array}{l}\text { \# of foreign MNC manufacturing firms in } \\
\text { region }\end{array}$ & -0.027 & 0.003 & -0.000 \\
\hline & & & \\
\hline $\begin{array}{l}\text { \# of domestic manufacturing firms in } \\
\text { region }\end{array}$ & $(0.034)$ & $(0.021)$ & $(0.013)$ \\
\hline & -0.006 & 0.011 & -0.017 \\
\hline region size & $(0.045)$ & $(0.016)$ & $(0.017)$ \\
\hline & 0.064 & -0.006 & 0.007 \\
\hline Observations & $(0.048)$ & $(0.028)$ & $(0.019)$ \\
\hline \# of firms & 454 & 1469 & 2573 \\
\hline R-squared & 205 & 482 & 966 \\
\hline Regressions with firm & 0.10 & 0.05 & 0.02 \\
\hline
\end{tabular}

Regressions with firm fixed effects.

R-squared for regression on within transformed variables, any impact of time invariant explanatory variables is purged.

Standard errors in parentheses.

* significant at $10 \%$; ** significant at 5\%; *** significant at $1 \%$.

Regressions include constant term.

For definition of availability measures see Table 5. 
Table 9: Interaction of availability and productivity

Dependent variable: $\ln ($ Imported materials / Sales)

\begin{tabular}{|l|l|l|l|}
\hline & $(1)$ & $(2)$ & $(3)$ \\
\hline & ODI & Foreign & Domestic \\
\hline Foreign MNC services firm availability & 0.270 & 0.009 & 0.062 \\
\hline & $(0.259)$ & $(0.137)$ & $(0.087)$ \\
\hline Domestic services firm availability & 0.218 & -0.182 & 0.147 \\
\hline & $(0.182)$ & $(0.117)$ & $(0.065)^{* *}$ \\
\hline $\begin{array}{l}\text { Foreign MNC services firm availability x } \\
\text { productivity }\end{array}$ & -0.013 & -0.029 & -0.013 \\
\hline & $(0.064)$ & $(0.034)$ & $(0.022)$ \\
\hline $\begin{array}{l}\text { Domestic services firm availability x } \\
\text { productivity }\end{array}$ & -0.037 & 0.046 & -0.015 \\
\hline & $(0.052)$ & $(0.032)$ & $(0.019)$ \\
\hline Labor productivity & 0.186 & -0.080 & 0.140 \\
\hline & $(0.147)$ & $(0.105)$ & $(0.062)^{* *}$ \\
\hline Firm size & -0.046 & 0.039 & 0.011 \\
\hline & $(0.027)^{*}$ & $(0.010)^{* * *}$ & $(0.007)$ \\
\hline Industry total services intensity & -0.012 & 0.005 & -0.001 \\
\hline & $(0.022)$ & $(0.009)$ & $(0.008)$ \\
\hline Industry local services intensity & 0.174 & -0.141 & -0.029 \\
\hline & $(0.089)^{*}$ & $(0.042)^{* * *}$ & $(0.040)$ \\
\hline $\begin{array}{l}\text { \# of foreign MNC manufacturing firms in } \\
\text { region }\end{array}$ & -0.025 & 0.002 & 0.001 \\
\hline & $(0.034)$ & $(0.021)$ & $(0.013)$ \\
\hline $\begin{array}{l}\text { \# of domestic manufacturing firms in } \\
\text { region }\end{array}$ & -0.007 & 0.011 & -0.017 \\
\hline & $(0.045)$ & $(0.016)$ & $(0.017)$ \\
\hline region size & 0.082 & -0.014 & 0.016 \\
\hline & $(0.049)^{*}$ & $(0.029)$ & $(0.020)$ \\
\hline Observations & 454 & 1469 & 2573 \\
\hline \# of firms & 205 & 482 & 966 \\
\hline R-squared & 0.11 & 0.05 & 0.02 \\
\hline Regs & & \\
\hline & & & \\
\hline
\end{tabular}

Regressions with firm fixed effects.

R-squared for regression on within transformed variables, any impact of time invariant explanatory variables is purged. Standard errors in parentheses.

* significant at $10 \%$; ** significant at $5 \% ; * * *$ significant at $1 \%$.

Regressions include constant term; for definition of availability measures see Table 5. 
Table 10: Interaction of availability and productivity with alternative availability measure

Dependent variable: $\ln ($ Imported materials / Sales)

\begin{tabular}{|l|l|l|l|}
\hline & $(1)$ & $(2)$ & $(3)$ \\
\hline & ODI & Foreign & Domestic \\
\hline Foreign MNC services firm availability & 0.005 & 0.002 & -0.001 \\
\hline & $(0.013)$ & $(0.004)$ & $(0.003)$ \\
\hline Domestic services firm availability & -0.002 & -0.001 & 0.001 \\
\hline & $(0.003)$ & $(0.001)$ & $(0.001)^{*}$ \\
\hline $\begin{array}{l}\text { Foreign MNC services firm availability x } \\
\text { productivity }\end{array}$ & -0.002 & -0.001 & 0.000 \\
\hline & $(0.004)$ & $(0.001)$ & $(0.001)$ \\
\hline $\begin{array}{l}\text { Domestic services firm availability x } \\
\text { productivity }\end{array}$ & 0.000 & 0.000 & -0.000 \\
\hline & $(0.001)$ & $(0.000)$ & $(0.000)$ \\
\hline Labor productivity & -0.022 & 0.016 & 0.025 \\
\hline & $(0.027)$ & $(0.015)$ & $(0.010)^{* *}$ \\
\hline Firm size & -0.025 & 0.039 & 0.012 \\
\hline & $(0.026)$ & $(0.010)^{* * *}$ & $(0.007)^{*}$ \\
\hline Industry total services intensity & -0.022 & 0.005 & -0.000 \\
\hline & $(0.022)$ & $(0.009)$ & $(0.008)$ \\
\hline Industry local services intensity & 0.134 & -0.152 & -0.028 \\
\hline & $(0.089)$ & $(0.042)^{* * *}$ & $(0.040)$ \\
\hline $\begin{array}{l}\text { \# of foreign MNC manufacturing firms in } \\
\text { region }\end{array}$ & -0.019 & 0.003 & 0.005 \\
\hline & $(0.033)$ & $(0.021)$ & $(0.013)$ \\
\hline $\begin{array}{l}\text { \# of domestic manufacturing firms in } \\
\text { region }\end{array}$ & 0.015 & -0.002 & -0.009 \\
\hline & $(0.046)$ & $(0.017)$ & $(0.017)$ \\
\hline region size & 0.068 & -0.030 & -0.029 \\
\hline & $(0.038)^{*}$ & $(0.021)$ & $(0.014)^{* *}$ \\
\hline Observations & 454 & 1469 & 2573 \\
\hline \# of firms & 205 & 482 & 966 \\
\hline R-squared & 0.08 & 0.05 & 0.02 \\
\hline Regs & & \\
\hline & & & \\
\hline
\end{tabular}

Regressions with firm fixed effects.

R-squared for regression on within transformed variables, any impact of time invariant explanatory variables is purged.

Standard errors in parentheses.

* significant at $10 \% ; * *$ significant at $5 \% ; * * *$ significant at $1 \%$.

Regressions include constant term.

For definition of alternative availability measures see appendix. 
Table 11: Instrumental variables estimation with alternative availability measure

Dependent variable: $\ln ($ Imported materials / Sales)

\begin{tabular}{|c|c|c|c|}
\hline & (1) & $(2)$ & (3) \\
\hline & ODI & Foreign & Domestic \\
\hline \multirow{2}{*}{ Foreign MNC services firm availability } & 0.111 & 0.031 & -0.050 \\
\hline & $(0.096)$ & $(0.013) * *$ & $(0.018) * * *$ \\
\hline \multirow[t]{2}{*}{ Domestic services firm availability } & -0.027 & -0.008 & 0.014 \\
\hline & $(0.028)$ & $(0.003)^{* *}$ & $(0.005)^{* * *}$ \\
\hline \multirow[t]{2}{*}{$\begin{array}{l}\text { Foreign MNC services firm availability } \mathrm{x} \\
\text { productivity }\end{array}$} & -0.029 & -0.008 & 0.014 \\
\hline & $(0.028)$ & $(0.003)^{* *}$ & $(0.005)^{* * *}$ \\
\hline \multirow[t]{2}{*}{$\begin{array}{l}\text { Domestic services firm availability } \mathrm{x} \\
\text { productivity }\end{array}$} & 0.008 & 0.002 & -0.004 \\
\hline & $(0.008)$ & $(0.001)^{* *}$ & $(0.001)^{* * *}$ \\
\hline \multirow[t]{2}{*}{ Labor productivity } & -0.027 & -0.047 & -0.012 \\
\hline & $(0.042)$ & $(0.027)^{*}$ & $(0.019)$ \\
\hline \multirow[t]{2}{*}{ Firm size } & 0.017 & 0.002 & 0.016 \\
\hline & $(0.011)$ & $(0.005)$ & $(0.005)^{* * * *}$ \\
\hline \multirow[t]{2}{*}{ Industry total services intensity } & -0.028 & 0.032 & 0.009 \\
\hline & $(0.071)$ & $(0.039)$ & $(0.036)$ \\
\hline \multirow[t]{2}{*}{ Industry local services intensity } & 0.043 & -0.157 & -0.002 \\
\hline & $(0.280)$ & $(0.240)$ & $(0.157)$ \\
\hline \multirow{2}{*}{$\begin{array}{l}\text { \# of foreign MNC manufacturing firms in } \\
\text { region }\end{array}$} & -0.106 & 0.029 & -0.019 \\
\hline & $(0.033)^{* * *}$ & $(0.028)$ & $(0.016)$ \\
\hline \multirow[t]{2}{*}{$\begin{array}{l}\text { \# of domestic manufacturing firms in } \\
\text { region }\end{array}$} & -0.093 & 0.039 & 0.006 \\
\hline & $(0.039)^{* *}$ & $(0.030)$ & $(0.017)$ \\
\hline \multirow[t]{2}{*}{ region size } & 0.181 & -0.162 & -0.054 \\
\hline & $(0.217)$ & $(0.133)$ & $(0.101)$ \\
\hline Observations & 179 & 557 & 843 \\
\hline Sargan (p-value) & 0.54 & 0.29 & 0.75 \\
\hline $\begin{array}{l}\text { First stage } \mathrm{F} \text { test (Foreign MNC services } \\
\text { firm availability) }\end{array}$ & 75.13 & 280.58 & 446.95 \\
\hline $\begin{array}{l}\text { First stage } \mathrm{F} \text { test (Domestic services firm } \\
\text { availability) }\end{array}$ & 77.93 & 268.53 & 349.91 \\
\hline $\begin{array}{l}\text { First stage } \mathrm{F} \text { test (Foreign MNC services } \\
\text { firm availability x productivity) }\end{array}$ & 12.26 & 191.25 & 234.97 \\
\hline $\begin{array}{l}\text { First stage } F \text { test (Domestic services firm } \\
\text { availability x productivity) }\end{array}$ & 12.93 & 190.83 & 217.13 \\
\hline Durbin-Wu-Hausman (p-value) & 0.55 & 0.53 & 0.53 \\
\hline
\end{tabular}

IV regressions. Services firm availability and interactions are endogenous variables. Instruments are twice lagged levels and differences of endogenous variables

Standard errors in parentheses.

* significant at $10 \% ; * *$ significant at $5 \% ; * * *$ significant at $1 \%$.

Regressions include constant term.

For definition of alternative availability measures see appendix. 
Table A1: Summary statistics for alternative services availability measure across regions, 2004

\begin{tabular}{|l|l|l|l|}
\hline Region & Dublin & South West \& East & Borders/Midlands/West \\
\hline $\begin{array}{l}\text { Effective \# of MNC } \\
\text { services firms }\end{array}$ & 28.05 & 6.99 & 6.87 \\
\hline & $(23.79)$ & $(7.48)$ & $(8.34)$ \\
\hline $\begin{array}{l}\text { Effective \# of Domestic } \\
\text { services firms }\end{array}$ & 96.76 & 34.73 & 8.29 \\
\hline & $(81.32)$ & $(38.26)$ & $(10.71)$ \\
\hline
\end{tabular}

Notes:

- Table reports means and standard deviations in parentheses.

- For definition of alternative measure see appendix. 